\title{
El poder de la escritura en el niño
} The power of writing in children

\author{
Has venido a este mundo \\ que no entiende nada sin palabras, casi sin palabras.
} ANTONIO PORCHIA

Los niños tienen ideas, teorías, hipótesis que ponen continuamente a prueba frente a la realidad y que confrontan con las ideas de otros. ${ }^{1}$

Desde que el niño incorpora el grafismo y la lectoescritura, pone en evidencia, a través de las características del trazo, la representación simbólica familiar, su propia imagen del cuerpo, su capacidad de resiliencia, su manera de procesar la información que recibe, etc. De ahí que el recurso de escritura sea un excelente medio para construir el psiquismo y favorecer la elaboración de la realidad. Es un proceso fundamental de enriquecimiento del universo simbólico.,3

El cuerpo es una producción humana impensable sin la palabra. El cuerpo allí enredado se expresa, habla, tanto si produce como si no lo hace. La escritura, entonces, es "construcción", que construye, en la tachadura, en la corrección, en el titubeo o en el espacio en blanco. ${ }^{3}$ Como mencionó Julio Cortázar en Bestiario: “Un trozo en blanco de la página será para usted un intervalo, apenas el puente que une mi letra de ayer a mi letra de hoy". Puede resultar útil analizar detalles del grafismo, que tienen que ver con límites mínimos y máximos de caracteres, y diferenciaciones cualitativas, que tienen que ver con las formas de las letras, con las diferencias de posiciones y sus combinaciones. Así como de la ubicación del cuerpo en el espacio y su entorno a la hora de escribir.

La escritura es metáfora del conocimiento humano, ya que le exige al cuerpo y al psiquismo, $y$, de este modo, amalgama, une lo disociado, lleva a pensar en un cuerpo-mente indisoluble. Permite plasmar todo lo que no evidencia la palabra hablada, los rincones del inconsciente. Según Henri Michaux, "el lápiz es un delator; dejar escrito es develar un secreto, perder el control de la palabra". ${ }^{3}$ Escribir es producir pensamiento.

La "teoría de Piaget" expone al sujeto que trata activamente de comprender el mundo que lo rodea y de resolver los interrogantes que este mundo plantea. Es un sujeto que construye sus propias categorías de pensamiento, al mismo tiempo que organiza su mundo. ${ }^{2}$ Es en la primera infancia que se organizan la expresividad de las emociones y los afectos primarios; es cuando se construye un rostro, aspecto notable de la identidad; cuando se instaura la postura, la gestualidad expresiva; es cuando se combina la mirada y la visión en proceso de comunicación y aprendizaje; cuando se gestan las capacidades de atención y escucha; cuando se construyen las bases de la comunicación; cuando la voz, cuerpo al fin, se construye tomando en referencia la prosodia familiar. La palabra, entonces, requiere, para ser escrita, el desarrollo del cuerpo y de una aptitud particular del organismo. Únicamente puede realizarse a partir de cierto grado de organización de la motricidad, que supone una fina coordinación de movimientos y un desarrollo espacial adecuado. ${ }^{3}$

Desde muy pequeños, los niños tienen experiencias en una sociedad alfabetizada, en la que van creando hipótesis acerca del mundo que los rodea y también acerca de la escritura, por lo que el jardín de infantes y la escuela deberían responder a esos conocimientos previos para potenciarlos, modificarlos y ampliarlos. El rol de la escuela es preponderante, ya que promueve la capacidad creativa, simbólica y lo social en interacción con el otro.

La escritura es un poderoso instrumento del pensamiento, en el que los que escriben aprenden sobre sí mismos y sobre el mundo, y comunican a otros sus percepciones, lo que permite tempranamente en los niños preescolares iniciar la producción escrita en sintonía con la adquisición de conocimientos sobre el mundo. $\mathrm{Al}$ mismo tiempo, escribir confiere el poder de crecer como persona e influir en el mundo. ${ }^{5}$ Influimos en el mundo cuando escribimos lo que sentimos, cuando reflejamos lo más recóndito de nuestra vida, cuando miramos al mundo y la sociedad de manera crítica y valiente.

En este sentido, la escritura no solo es una herramienta cultural y social, sino también una actividad cognitiva-simbólica compleja que implica la construcción de significados por parte de los niños e impacta en su desarrollo intelectual al involucrar procesos cognitivos superiores y metacognitivos. ${ }^{5}$ La alteración en la construcción de las manifestaciones corporales funcionaría como un indicador de anomalías en el desarrollo.

El aprendizaje de la escritura requiere de diferentes etapas, según Ferreiro. En la etapa prefonética, no hay comprensión del principio alfabético, por tanto no hay comprensión grafismofonema. En la etapa fonética, el niño comienza a detectar sílabas y el alfabeto. Y, en la etapa visofonética, escribe respetando todos los sonidos y los representa adecuadamente con su letra. 
Ferreiro estableció: “Escribir requiere del niño no solamente el trazado de letras, sino la conciencia de que lo que se dice se puede escribir".

La escritura se configura en un espacio donde el lenguaje encuentra un lugar y una visibilidad. Siendo único su trazo, tiene la capacidad de ser múltiple. La letra entra para no salir jamás. ${ }^{3}$ La escritura se asume como proceso cognitivo, como un conjunto de procesos intelectuales que un escritor desarrolla mientras produce un texto. Si bien el que escribe no transforma el mundo (algunos dicen que sí), sí puede transformarse a sí mismo: y, en esa transformación, transforma también su manera de pensarlo. ${ }^{4}$

Como dijo Pescetti, reconocido escritor infantil, a través de la escritura, "se puede contar la vida igual a como es, o contarla como nos gustaría que fuera. Se pueden contar historias que nos gustaron o que no y poder contarlas para no sentirnos solos. Un día terrible, o un día maravilloso, de acuerdo con lo que vamos a contar".

De ahí que, como él mismo dijo, ofrecerle al niño un lápiz es darle "una varita mágica, una batuta de director de orquesta y con la forma de un pararrayos, aunque más pequeño". ${ }^{6}$

Dra. Paula Arighi

Hospital Nacional de Pediatría "Prof. Dr. Juan P. Garrahan"

Buenos Aires

paulaarighi@yahoo.com.ar

http:/ /dx.doi.org/10.5546/aap.2016.402

\section{REFERENCIAS}

1. Sinclair H. Prólogo. En Ferreiro E, Teberosky A. Los sistemas de escritura en el desarrollo del niño. México DC: Siglo XXI; 1989:11-3.

2. Ferreiro, E. Teberosky A. La pertinencia dela teoría de Piaget para la comprensión de los procesos de lectura y escritura. En Ferreiro E, Teberosky A. Los sistemas de escritura en el desarrollo del niño. México DC: Siglo XXI; 1989:21-7.

3. Calmels D. El cuerpo en la Escritura. Buenos Aires: Biblos; 2014:9-41.

4. Bas A, Klein I, Lotito L, Vermino T. Escribir: Apuntes sobre una práctica. Buenos Aires: Eudeba; 1999:15-25.

5. Díaz Oyarce C, Price Herrera MF. ¿Cómo los niños perciben el proceso de la escritura en la etapa inicial? Estud Pedagóg 2012;38(1):215-33.

6. Luis Pescetti [Internet]. [Consulta: 12 de febrero de 2016]. Disponible en. http://www.luispescetti.com/.

\section{El símbolo y su función terapéutica: en busca de sus fundamentos científicos Symbols and their therapeutic role: Looking for scientific grounds}

La historia de la ciencia y tecnología nos enseña que frecuentemente saberes que gozaron de gran prestigio en la antigüedad, fueron luego desestimados y olvidados, para finalmente ser redescubiertos o rejerarquizados en épocas posteriores. $^{1}$

En este sentido, mucho antes de la instalación de lo que fueron las formas embrionarias de la medicina moderna, tales como la teoría de los cuatro humores (siglos V A.C. - XV D.C.), la medicina iatromecánica y la medicina iatroquímica (siglos XVI-XVII), la asistencia de los enfermos se basó en lo que hoy conocemos como medicina primitivista, la cual se servía del pensamiento mágico y del impacto clínico de la eficacia simbólica. ${ }^{2}$

Según el antropólogo Levi-Strauss la eficacia simbólica es el fenómeno por el cual una persona, una narración o una imagen cobra, en un determinado momento, la categoría de símbolo, y a partir de entonces se constituye en el instrumento por el cual un acontecimiento en la vida de una persona adquiere un sentido mistérico, tras lo cual dicho elemento (símbolo) logra operar transformaciones en el ámbito de lo real. ${ }^{3,4}$

Sin embargo, para que la eficacia simbólica pueda concretarse el símbolo tiene que operar dentro de un sistema de referencia que lo sustente, es decir dentro de un colectivo que crea y tenga fe en él. Un ejemplo paradigmático en este sentido es el del médico chamán, en quien el enfermo deposita su esperanza en su supuesto mágico poder, fenómeno que éste refuerza ejerciendo una estética plagada de simbología y rituales, enmarcados en su atuendo, gestualidad, y en el ritmo iterativo con que ejecuta sus cánticos, danzas e instrumentos musicales. ${ }^{5}$ Sin ir más lejos, esto nos recuerda cuanto juega lo simbólico en la consulta médica moderna, como lo señalara Balint al acuñar el concepto de que la figura del médico es terapéutica per se. ${ }^{6}$

Por otro lado, debe recordarse que nuestro acceso al mundo (interior y exterior) se realiza en forma indirecta, es decir a través de representaciones, sean éstas símbolos (imágenes) 